Original article

\title{
HER-2/neu gene analysis on endoscopic biopsy samples and gastric resection materials in gastric carcinomas
}

\author{
Ali Zisan Genc, Resit Dogan Koseoglu, Akgul Arici, Osman Demir \\ Tokat Gaziosmanpasa University, School of Medicine, Tokat, Turkey
}

Received 06 February 2019, Revised 20 August 2019, Accepted 02 November 2019

C 2019, Genc A.Z., Koseoglu R.D., Arici A., Demir O.

(C) 2019, Russian Open Medical Journal

\begin{abstract}
Objective - HER-2/neu assay in gastric cancers is routinely evaluated by immunohistochemistry and fluorescent in situ hybridization methods because the monoclonal antibody trastuzumab developed against HER-2/neu give rise to significant improving on the survival. In the HER-2/neu evaluation, some problems related to the sampling process, analysis method, tumor biology and heterogeinity are encountered. Our aim in the present study was to analyze these evaluation problems on endoscopic biopsy samples and resection materials of our cases with gastric carcinoma.

Material and Methods - The study included 109 gastric cancer cases. The analyses were realized on the resection materials of the 109 cases and the endoscopic mucosa biopsies of 43 out of these 109 cases. Immunohistochemistry was applied on mucosa biopsies and, tumor sections of resections, while fluorescent in situ hybridization was performed on tumor sections of resections (21 cases). The assays results were compared with each other and clinicopathological parameters.

Results - Our rate of $\mathrm{HER}-2 /$ neu positivity (IHC3+ and IHC2+/FISH+ cases) was $6.42 \%$. The compatibility rate between the rates of overexpression and amplification in resections was $90.5 \%$ while the compatibility ratio between the overexpression rates of mucosa samples and resections was $95.4 \%$. The false negativity rate on mucosa biopsies was detected as $4.65 \%$. HER-2/neu status was not correlated with unfavorable clinicopatological features.

Conclusion - Our gene positivity rate was near the lower limit of the range reported in the literature. Our compatibility rate between the results of immunohistochemistry and fluorescent in situ hybridization was over $90 \%$. However our false negativity rate in mucosa biopsy analysis was low according to the literature. In order to preclude false negativity arising from tumor heterogeinity, we think that immunohistochemistry should be applied on the whole section.
\end{abstract}

Keywords: HER-2/neu, gastric adenocarcinoma, endoscopic biopsy, immunohistochemistry, in situ hybridization.

Cite as Genc AZ, Koseoglu RD, Arici A, Demir O. HER-2/neu gene analysis on endoscopic biopsy samples and gastric resection materials in gastric carcinomas. Russian Open Medical Journal 2019; 8: e0410.

Correspondence to Resit Dogan Koseoglu. E-mail: residdogan@hotmail.com.

\section{Introduction}

Gastric cancer/adenocarcinoma (GCa) is the fifth most common cancer in the world and the second most common cause of cancer related deaths worldwide [1, 2]. In our country, the incidence of GCa in males and females is 14.3/100,000 and $6.5 / 100,000$, respectively. Among the top 10 cancer types, it is fifth in males and sixth in females [3]. GCa frequency varies geographically and diet, lifestyle, economic status and $H$. pylori infection are important predisposing factors [1]. GCa incidence in the Western countries has declined over the past decades, but there has been no significant change in cancer-related mortality. Five-year survival rates are still between $10-30 \%$ despite improvements in diagnosis and treatment [4].

Biological heterogeneity in GCa leads to variable prognosis. This heterogeneity has led to analysis of some factors that may also be indicative of the indications of novel treatment modalities, other than conventional prognostic factors, such as tumor histological type, tumor invasion depth (TID), lymph node metastasis (LNM), distant metastasis. Over-amplification of the human epidermal growth factor receptor (HER-2/neu, c-erbB2) gene and overexpression of the protein encoded by this gene have been described in many human malignant tumors. These include breast, colon, lung, over and GCa [5].

HER-2/neu gene is mapped in 17q12-q21 and is a protooncogene that encodes a transmembrane tyrosine kinase receptor from the epidermal growth factor receptor family at 185 kilograms Dalton molecular weight [6]. HER-2/neu gene amplification/overexpression in tumor cells plays an important role in cell proliferation, leading to excessive receptor expression. Amplification and/or overexpression in breast cancers are associated with LNM and unfavorable prognosis.

Trastuzumab (Herceptin ${ }^{\circledR}$ : F Hoffmann-La Roche, Base, Switzerland) is a recombinant human monoclonal antibody against to the HER-2/neu receptor. Trastuzumab exhibits anti-tumor activity by inhibiting HER-2/neu-associated tumor cell proliferation, exhibiting antibody-dependent cytotoxicity, accumulating cytotoxic T-lymphocytes in the tumor region, and 
activating apoptosis in tumor cells. It may also play a role in antitumor activities by causing changes in adhesion, migration and differentiation processes in cells [7]. Trastuzumab is used as an effective treatment for HER-2/neu positive early and metastatic breast cancer patients due to its anti-tumor activities [8].

Our goals in the present study, by using methods of immunohistochemistry (IHC) and flouresan in situ hybridization (FISH) in our series, were to analyze HER-2/neu status, to compare to the assay results of biopsy and resection, to examine hetereogeinity of HER-2/neu, to reveal probable relations between gene status and conventional clinicopathologic parameters (CCP).

\section{Material and Methods}

\section{Study design}

The study was realized on the paraffine blocks of 109 cases of primary GCa after approval from the Ethics Committee of the Faculty of Medicine. The cases included in the study were surgically resected between 2000-2014. Pathologic archive materials were reviewed and appropriate blocks for IHC were selected. CCP analyzed in the study; histological grade, tumor size, TID, blood and lymphatic vessel invasion, perineural/neural invasion, LNM and metastatic lymph node number $(<10$, and $\geq 10)$. HER-2/neu IHC analyses were performed on mucosa biopsies (in 43 of $109 \mathrm{GCa}$ cases) and tumor tissues in gastric resections (109 GCa cases). In the study, IHC analyzes were performed on a fully automated IHC device of Leica brand Bond model (Leica Biosystems, Nussloch, Germany) by using HER-2/neu primary antibody (Clone; e24001+ 3B5, dilution; $1 / 400$, antigen retriveal; citrate, incubation period; 30 minutes, Thermo Fisher Scientific, Fremeont, USA). Breast cancer tissue sample known to be HER$2 /$ neu positive was used as positive control. The tissue sections were incubated with phosphate buffer solution instead of the primary antibody for negative control.

\section{Evaluation of HER-2/neu immune expression}

Basal or basolateral incomplete membranous staining in Ushape without luminal border staining of glandular cells was considered significant due to the natural histomorphological character of normal gastric mucosal glands and tumors. IHC analyses were performed in whole section areas of tumors due to HER-2/neu heterogeneity in GCa. The revised scoring system (RSS) of the Hercep-Test ${ }^{\mathrm{TM}}$ was used for HER-2/neu scoring in GCa (Table 1) [9].

$\mathrm{IHCO}$ and $\mathrm{HCC}+$ immunostainings were considered as "negative" while $\mathrm{IHC3}_{+}$immunostaining was accepted as "positive". IHC2+ immunostaining was accepted as "equivocal positive" (Figure 1). IHC2+ immunostaining are directed to FISH analysis in general practice. HER-2/neu IHC scores on endoscopic mucosa biopsy samples and, tumor sections in gastric resections were defined by the abbreviations of biopsy- $\mathrm{IHC}(\mathrm{Bx}-\mathrm{IHC})$ and resection-IHC (R-IHC), respectively. In our study, the FISH method for HER-2/neu was applied manually. The process was carried out on paraffin sections with a thickness of 3 micrometers. FISH was performed on the tumor sections of 21 cases showing HER-2/neu immune expression. FISH analysis was not performed in the cases without immune expression (IHCO). Zytovision brand Zytolight SPEC HER2/CEN17 dual color probe kit (ZytoVision, Bremerhaven, Germany) was used for FISH analysis.

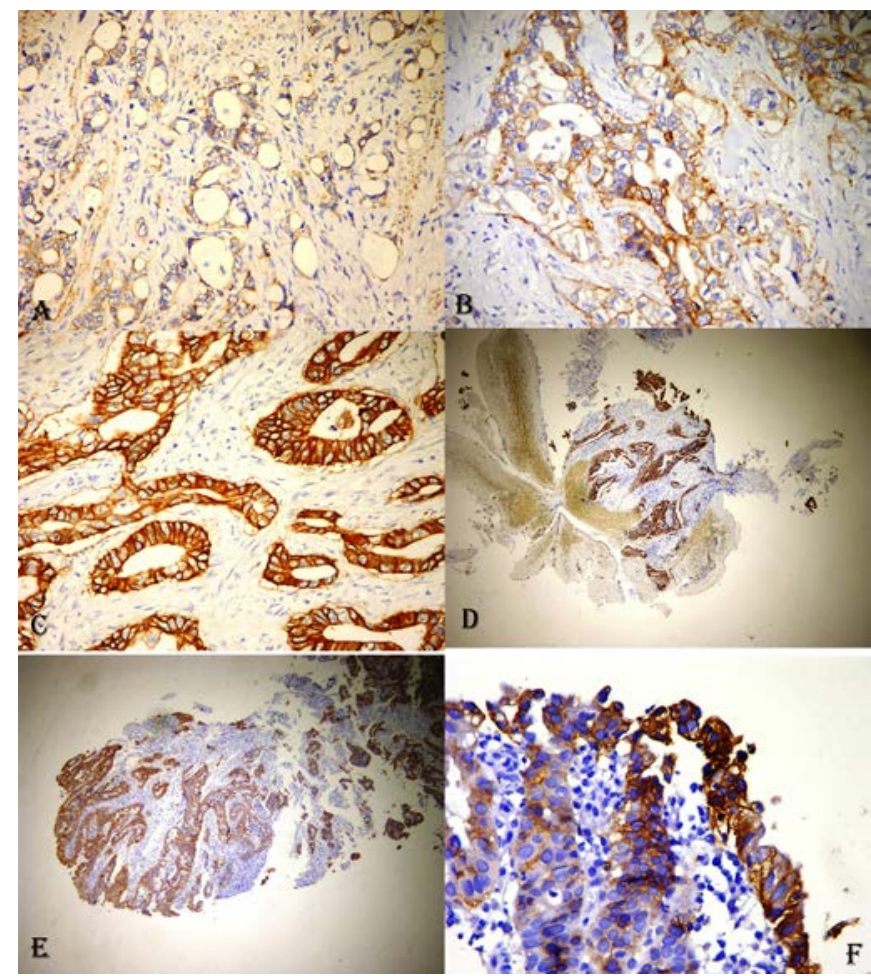

Figure 1. A. Weak partial membranous immunostaining in intestinal type adenocarcinoma with IHC1+ immune expression for HER-2/neu (DAB, X20). B. Moderate, weak complete/basolaretal membranous immunostaining in intestinal type adenocarcinoma with $\mathrm{IHC2}+$ immune expression for HER-2/neu (DAB, X20). C. Strong complete/basolateral immunostaining in intestinal type adenocarcinoma with IHC 3+ immune expression for HER-2/neu (DAB, X20). D. Tumor showing strong complete membranous HER-2/neu immunostaining in endoscopic biopsy specimen (DAB, X4). E. Tumoral infiltration showing heterogenous immune expression for HER-2/neu in endoscopic biopsy specimen (DAB, X10). F. High magnification view of HER-2/neu positive tumor cell clone in endoscopic biopsy specimen (DAB, X40).

\section{FISH assessment}

With the use of appropriate filter sets (DAPI, FITC, Texas Red, TRITC and Triple filters), hybridization signals were observed in green and orange-yellow colors. While the green signal represented the HER-2/neu gene, the orange-yellow signal represented chromosome 17 centromere (CEN17). In cells without gene amplification, the HER-2 gene was represented by 2 green signals while the chromosome 17 centromere was marked by 2 orange-yellow signals. On the PTT sample of the each case, at least 20 nuclei without overlapping were assessed for FISH analysis. If the ratio of the number of green signals to the number of yellow signals was $\geq 2$, it was considered positive for gene amplification (Figure 2). For the optimal evaluation, the signals had to be within the integrity-preserved nuclei and to be seen separately from each other. Chromosome 17 polysomy is a condition that can lead to false positive results. This condition must be defined and taken into account during the evaluation. If more than $6 \%$ of the counted tumor cells had 3 or more orange-yellow CEN17 signals, this was defined as the chromosome 17 polysomy [10]. The reliability of the hybridization results was provided by co-staining and coevaluating the sections and the positive/negative controls provided with the kit. 


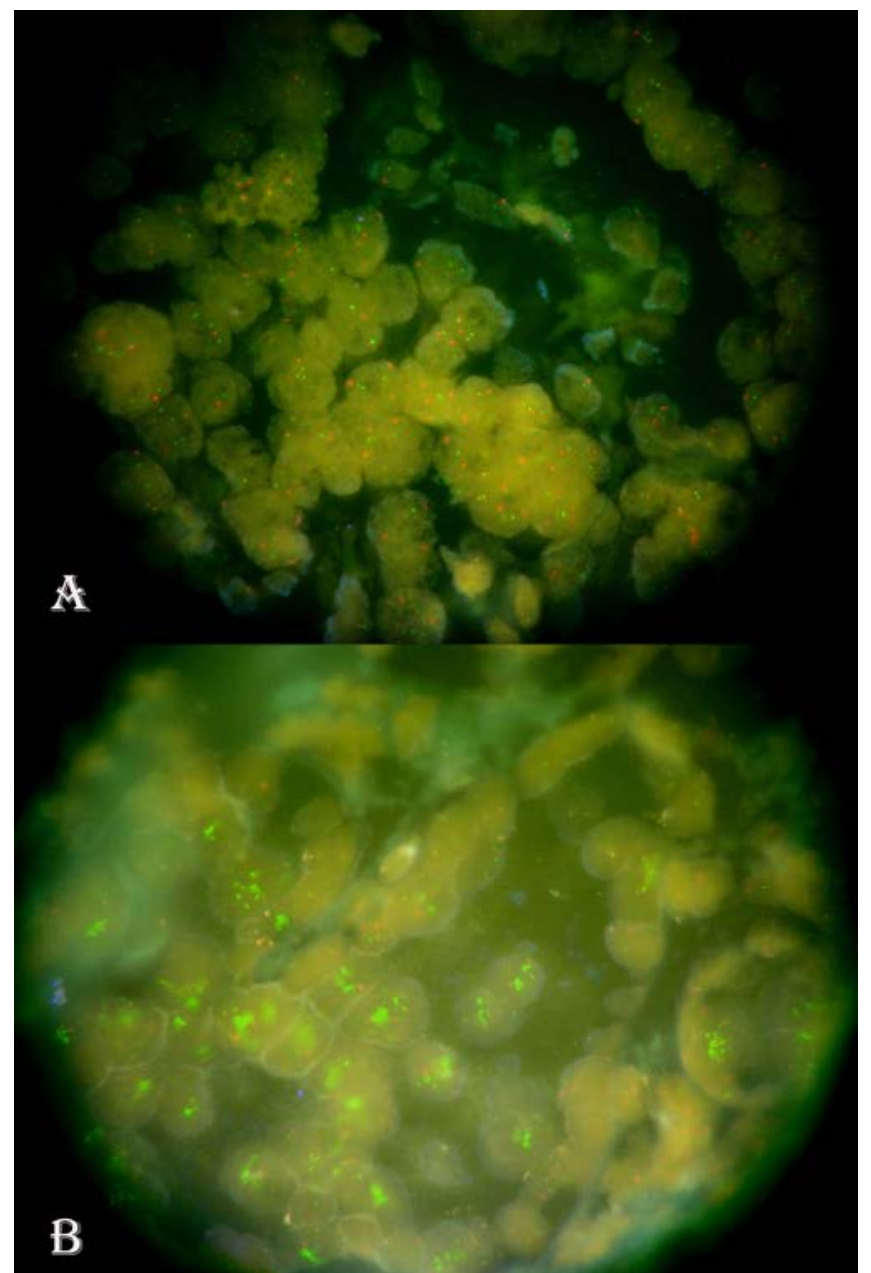

Figure 2. A. Two green signals representing HER-2/neu gene and two orange signals representing CEN17 in tumor cell nuclei of a case without HER-2/neu gene amplification (DAPI, X1000). B. The increased green signals forming clusters in tumor cell nuclei of a case with HER-2/neu gene amplification (DAPI, X1000).

\section{Statistical analysis}

Shapiro-Wilk's test of normality of continuous variables was examined by histogram and q-q plot graphs. The significance test of difference between two averages was used when looking for differences between two groups in terms of continuous variables. One-way ANOVA was used when there was a difference between two groups in terms of continuous variables. The relationship between qualitative variables was examined by Chi-square $\left(\chi^{2}\right)$ tests. Quantitative variables were expressed in terms of arithmetic mean with standard deviation $(\mathrm{M} \pm \mathrm{SD})$ and qualitative variables in number and percentage. P-value was accepted statistically significant when it was calculated as less than 0.05 . Statistical analysis was performed by using Statistical Packages for the Social Sciences (SPSS) version 19 commercial software (IBM Corp.; Armonk, NY, USA).

\section{Results}

The mean age of 109 cases was $66.9 \pm 9.8$ year. Eighty cases (73.4\%) were male and 29 (26.6\%) were female. CCP data was given in Table 2.
The rate of $\mathrm{R}-\mathrm{IHC}+$ cases was $5.5 \%$ ( 6 cases) while there were only 2 cases $(4.7 \%)$ wich were $\mathrm{Bx}-\mathrm{IHC} 3+$. Gene amplification was detected in 9 of 21 cases (42.9\%) that had been performed FISH analysis (Table 2).

Gene amplificiation correlated with histological type. Six of the 21 cases which performed FISH analysis were diffuse type and all of these diffuse type cases were FISH negative. Nine (60\%) of the 15 cases with intestinal type were FISH+ $(p=0.019)$ (Table 3$)$.

There was no correlation between HER-2/neu status and tumor localization. R-IHC scores of cardia and non-cardia tumors were close proportions to each other. Gene amplification rates of cardia and non-cardia tumors were $57.1 \%$ and $35.7 \%$, respectively. Although a higher gene amplification rate of cardia tumors, there was no statistical significance $(p=0.397)$ (Table 4).

Grade correlated with gene amplification. Gene amplification was clustered in grade II tumors. Six (66.7\%) of the cases with amplification were grade II $\left(\chi^{2}=6.3, p=0.043\right)$ (Table 3$)$.

Significant correlation was determined between IHC scores of resections and biopsies. R-IHC score corresponding to 32 cases (86.5\%) with Bx-IHCO was also IHCO. There were only 2 cases that they were $\mathrm{Bx}-\mathrm{IHC} 3+$ and their $\mathrm{R}-\mathrm{IHC}$ scores were also $3+\left(\chi^{2}=43.0\right.$, $\mathrm{p}<0.001$ ) (Table 4).

In the group performed FISH analysis, all of 5 patients with Bx$\mathrm{IHCO}$ were non-amplified while 2 patients with $\mathrm{Bx}-\mathrm{IHC}+$ showed gene amplification. Two of the 3 patients with $\mathrm{Bx}-\mathrm{IHC}+(66.7 \%)$ had gene amplification $\left(\chi^{2}=7.2, p=0.027\right)$ (Table 4). $\mathrm{R}$-IHC scores of these two cases were $2+$ and $3+$. In other words, these two cases were the false negative cases according to the HER-2/neu immunohistochemical analysis performed on endoscopic mucosa biopsies and therefore our false negativity (FN) ratio was $4.65 \%$. HER-2/neu expressions in the resections correlated with gene amplification. Six cases with R-IHC3+ and one case with R-IHC2+ showed gene amplification. Of the 14 cases with R-IHC1+, only 2 $(14.3 \%)$ showed gene amplification $\left(\chi^{2}=14.0, p<0.001\right)$ (Table 5).

\section{Discussion}

HER-2/neu amplification/overexpression has also been determined in other tumors outside the breast, especially in GCa. HER-2/neu positivity ranged from $6.8 \%$ to $42 \%$ in the different GCa series [9, 11-13]. According to the method applied and scoring systems, there were significant differences among the positivity rates. HER-2/neu positivity rates ranged from $6.8 \%$ to $34 \%$ in the studies using IHC $[14,15]$. In the studies using ISH, this rate ranged from $7.1 \%$ to $42.6 \%[14,16,17]$. HER-2/neu positivity rates changed in a narrower range (9.4\%-15.7\%) in the studies using the revised scorring system [18-22]. In the present study, our overexpression rate was $5.5 \%$ (R-IHC3+ cases). Our rate was lower than those of other studies using the revised scorring system. The most important reason might be that the proportion of diffuse carcinomas is as high as $35.8 \%$. When we considered only intestinal carcinomas, our rate of overexpression was $8.6 \%$ (only R-IHC3+ cases). Both of these rates, however, were close to the lower limit of the range in the literature. In our study, e2$4001+3 B 5$ antibody approved by FDA (Food Drug Administration) was used. In the literature, HercepTest ${ }^{\mathrm{TM}}$ or $4 \mathrm{~B} 5$ antibodies were recommended because of their higher sensitivity and specificity [2]. In the present study, another reason for relatively low the R$\mathrm{IHC}+$ rate might be the clone we used in our study. 
Table 1. Revised scoring system for HER-2/neu immune expression in gastric carcinoma

\begin{tabular}{ll}
\hline Surgical specimen & \multicolumn{1}{c}{ Biopsy } \\
\hline $\begin{array}{l}\text { No membranous staining or staining of }<10 \% \\
\text { of the tumor cells }\end{array}$ & $\begin{array}{l}\text { No membranous staining or staining only in rare cells (less than } 5 \\
\text { cohesive cells) }\end{array}$ \\
$\begin{array}{l}\text { Recognizable, incomplete, poorly membranous staining in } \\
\text { more than } 10 \% \text { of tumor cells }\end{array}$ & $\begin{array}{l}\text { Staining is weak or detected in only one part of the membrane of } \\
\text { at least } 5 \text { cohesive cells }\end{array}$ \\
$\begin{array}{l}\text { Complete or basolateral/lateral, moderate- weak } \\
\text { membranous staining in more than } 10 \% \text { of tumor cells, }\end{array}$ & $\begin{array}{l}\text { Moderate/weak complete or basolateral membranous staining of } \\
\text { at least } 5 \text { cohesive cells }\end{array}$ \\
$\begin{array}{l}\text { Complete or basolateral/lateral, strong membranous } \\
\text { staining in more than } 10 \% \text { of tumor cells, }\end{array}$ & $\begin{array}{l}\text { Strong complete or basolateral membranous staining of at least } 5 \\
\text { cohesive cells }\end{array}$ \\
\hline
\end{tabular}

Table 2. Conventional clinicopathological parameters, IHC scores and FISH results of the study group

\begin{tabular}{|c|c|c|c|}
\hline Parameters & Category & $n$ & $\%$ \\
\hline \multirow[t]{2}{*}{ Gender } & Male & 80 & 73.4 \\
\hline & Female & 29 & 26.6 \\
\hline \multicolumn{4}{|l|}{ Mean age, years } \\
\hline Mean age of male, years & $66.9 \pm 10.0$ & 80 & $73.4^{-}$ \\
\hline Mean age of female, years & $66.8 \pm 9.7$ & 29 & 26.6 \\
\hline \multirow[t]{2}{*}{ Categorized age, years } & $\leq 6 \overline{5}$ & 47 & $43.1^{\circ}$ \\
\hline & $>65$ & 62 & 56.9 \\
\hline \multirow[t]{2}{*}{ Tumor histological type } & Intestinal & 70 & 64.2 \\
\hline & Diffuse & 39 & 35.8 \\
\hline \multicolumn{4}{|l|}{ Average tumor size, $\mathrm{mm}$} \\
\hline \multirow[t]{3}{*}{ Categorized tumor size, mm } & $\leq 50^{-}$ & 44 & $40.4^{-}$ \\
\hline & $51-69$ & 16 & 14.7 \\
\hline & $\geq 70$ & 49 & 45.0 \\
\hline \multirow[t]{3}{*}{ Histological grade } & Well (Grade I) & 6 & 5.5 \\
\hline & Moderate (Grade II) & 48 & 44.0 \\
\hline & Poor (Grade III) & 55 & 50.5 \\
\hline \multirow[t]{3}{*}{ Tumor invasion depth } & $\overline{\mathrm{T} 2}$ & 10 & 9.2 \\
\hline & T3 & 47 & 43.1 \\
\hline & T4 & 52 & 47.7 \\
\hline \multirow[t]{2}{*}{ Lymphatic vessel invasion } & Ábsent & 19 & $17.4^{-}$ \\
\hline & Present & 90 & 82.6 \\
\hline \multirow[t]{2}{*}{ Blood vessel invasion } & Äbsent & 60 & 55.0 \\
\hline & Present & 49 & 45.0 \\
\hline \multirow[t]{2}{*}{ Neural/Perineural invasion } & Absent & 51 & 46.8 \\
\hline & Present & 58 & 53.2 \\
\hline \multirow[t]{3}{*}{ Lymph node metastasis } & No metastasis & 18 & $16.5^{-}$ \\
\hline & Positive node $<10$ & 56 & 51.4 \\
\hline & Positive node $\geq 10$ & 35 & 32.1 \\
\hline \multirow[t]{4}{*}{$\mathrm{BX}-\mathrm{IHC}(\mathrm{HER}-2 /$ neu $)$} & Score 0 & 37 & 86.0 \\
\hline & Score 1 & 4 & 9.3 \\
\hline & Score 2 & 0 & 0 \\
\hline & Score 3 & 2 & 4.7 \\
\hline \multirow[t]{4}{*}{$\mathrm{R}-\mathrm{IHC}(\mathrm{HER}-2 / \mathrm{neu})$} & Score 0 & 88 & 80.7 \\
\hline & Score 1 & 14 & 12.8 \\
\hline & Score 2 & 1 & 0.9 \\
\hline & Score 3 & 6 & 5.5 \\
\hline \multirow[t]{2}{*}{$\overline{F I S H}$} & Negative & 12 & $57.1^{-}$ \\
\hline & Positive & 9 & 42.9 \\
\hline
\end{tabular}

$\mathrm{Bx}-\mathrm{IHC}$, endoscopical mucosa biopsy samples immunohistochemistry score; $\mathrm{R}-\mathrm{IHC}$, tumor section of gastric resection immunohistochemistry score; IHC, immunohistovchemistry; FISH, fluorescence in situ hybridization.

Jorgensen et al. [23] suggested that gene amplification rates changed in a narrower range (8.7\%-18.1\%) in their review article. This could be explained by the fact that ISH was a more quantitative method. In our series, FISH analysis was not applied to all cases. Gene amplification was detected in 9 (42.9\%) of 21 cases with immune expression. This rate did not represent the overall study group. When amplified cases were distributed according to R-IHC scores, the distribution was as follows; 6 amplified cases; R-IHC3+, 1 amplified case; R-IHC2+, and 2 amplified cases; R-IHC1+. According to these results, we accepted that the phenotype of $\mathrm{R}-\mathrm{IHC} 3+$ and $\mathrm{R}-\mathrm{IHC2}+/ \mathrm{FISH}+$ was as actual positivity for HER-2/neu. According to this, we can accept that our current positivity rate for HER-2/neu is $6.4 \%$ (7 cases). Although two cases with $\mathrm{R}-\mathrm{IHC1}+$ showed amplification, they were not evaluated in the HER-2/neu positive category because of IHC1+/FISH+ phenotype had benefit from trastuzumab treatment in a lower rate according to the $\mathrm{IHC} 2+/ 3+/ \mathrm{FISH}+$ phenotype.

Gastroesophageal region cancers (GERCa) had a higher HER$2 /$ neu positivity rate than other gastric regions [17]. HER-2/neu positivity rate in GERCa was $32.2 \%$ according to the ToGa study (the Trastuzumab for Gastric Cancer trial) [24]. We did not determine a significant correlation between HER-2/neu status and tumor location. Our HER-2/neu positivity rate (R-IHC3+ and R$\mathrm{IHC}+/ \mathrm{FISH}+$ ) in tumors with cardia location was $8.8 \%$ while this rate was $5.3 \%$ in cases with non-cardia location. Although gene amplification rates were different between cardia (57.1\%) and non-cardia tumors (35\%), there was no a statistical significance $(p=0.397)$. HER-2/neu positivity rate in our cases with cardia location was lower than those reported in the literature. Cutsem et al suggested that GERCa were different from GCa with other location in terms of etiological and pathogenetic mechanisms. Higher HER-2/neu positivity rates in GERCa were explained on the basis of their discrete etiopathogenetic characteristics and their predominantly intestinal type morphology $[25,26]$.

In GCa, HER-2/neu positivity has been associated with poorer prognosis, more aggressive clinical course and shorter survival times, although there were also reports in the opposite direction $[12,13,17]$. The accurate assessment of HER-2/neu gene status has become important as it has been shown that trastuzumab treatment prolongs the mean survival time in patients with HER2/neu positive advanced GCa [27-29]. In TOGA study, HER-2/neu positivity rate (IHC3+ and $\mathrm{IHC2}+/ \mathrm{FISH}+$ cases) was $22.1 \%$. HER2 /neu positivity rate in GERCa was higher than that of GCa (33\% vs $21 \%)$. Intestinal type cancers showed higher HER-2/neu positivity than diffuse types (31.8\% versus 6.1\%) [24]. Rüschoff et al reported that HER-2/neu positivity rate was $22.8 \%$ in their study [30]. This rate was very close to that (22.1\%) of TOGA study [24]. In the same study, FISH analysis was performed in 152 cases. All of $\mathrm{IHC} 3+$ cases showed gene amplification, while $32 \%$ of $\mathrm{IHC} 2+$ cases and $5 \%$ of IHC1+ cases had gene amplification [30]. Rüschoff et al. concluded that 4B5 antibody was as sensitive as HercepTest ${ }^{\mathrm{TM}}$ and showed higher compatibility between laboratories, and reached a higher rate of FISH positivity in IHC $3+$ cases [30]. In our study, all of the cases with $\mathrm{R}-\mathrm{IHC2}+$ and $3+$ showed gene amplification, whereas $14.3 \%$ of the IHC1+ cases ( 2 cases) were $\mathrm{FISH}$ positive. Our gene amplification ratio in $\mathrm{R}-\mathrm{IHC1}+$ group was higher than that of Rüschoff et al [30]. Our high gene amplification rate in R-IHC1+ group might be due to preanalytical technical reasons. 
Table 3. HER-2/neu status in primary and mucosal tumor tissues according to tumor histological type, histological grade and tumor invasion depth

\begin{tabular}{|c|c|c|c|c|c|c|c|c|c|c|c|c|c|c|c|c|c|}
\hline \multirow[t]{2}{*}{$P \ldots S$} & \multirow[t]{2}{*}{ Category } & \multicolumn{5}{|c|}{ Tumor histological type } & \multicolumn{6}{|c|}{ Histological grade } & \multicolumn{5}{|c|}{ Tumor invasion depth } \\
\hline & & intestinal & Diffuse & Total & $x^{2-}$ & $p$ & Well & Moderate & Poor & Total & $x^{2-1}$ & $p$ & $\mathrm{~T} 2$ & $\mathrm{~T} 3$ & $\mathrm{~T} 4$ & Total & $p$ \\
\hline \multirow[t]{5}{*}{$\mathrm{Bx}-\mathrm{IHC}$} & Score 0 & $22(84.6)$ & $15(88.2)$ & $37(86.0)$ & & & $2(100)$ & $17(81.0)$ & $18(90.0)$ & $37(86.0)$ & & & $8(100)$ & $9(69.2)$ & $20(91.0)$ & 19(76.0) & \\
\hline & Score 1+ & $2(7.7)$ & 2 (11.8) & $3(7.0)$ & & & 0 & $2(9.5)$ & $2(10.0)$ & $4(9.3)$ & & & 0 & $3(23.1)$ & $1(4.5)$ & $4(16.0)$ & \\
\hline & Score 2+ & 0 & 0 & 0 & 1.5 & 0.471 & 0 & 0 & 0 & 0 & 2.4 & 0.656 & 0 & 0 & 0 & 0 & 5.20 .264 \\
\hline & Score 3+ & $2(7.7)$ & 0 & $2(4.7)$ & & & 0 & $2(9.5)$ & 0 & $2(4.7)$ & & & 0 & $1(7.7)$ & $1(4.5)$ & $2(8)$ & \\
\hline & Total & $26(60.5)$ & $17(39.5)$ & $43(100)$ & & & $2(4.7)$ & $21(48.8)$ & $20(46.5)$ & $43(100)$ & & & $8(18.6)$ & $13(30.2)$ & $22(51.2))$ & $43(100)$ & \\
\hline \multirow[t]{5}{*}{$\mathrm{R}-\mathrm{IHC}$} & Score 0 & $55(78.6)$ & $33(84.6)$ & $88(80.7)$ & & & $4(66.7)$ & $37(77.1)$ & $47(85.5)$ & $88(80.7)$ & & & $10(100)$ & $34(72.4)$ & $44(84.6)$ & $88(80.7)$ & \\
\hline & Score 1+ & $8(11.4)$ & $6(15.4)$ & $14(12.8)$ & & & 1 (16.6) & $6(12.5)$ & $7(12.7)$ & 14 (12.9) & & & 0 & 9 (19.1) & $5(9.6)$ & $14(12.8)$ & \\
\hline & Score 2+ & $1(1.4)$ & 0 & $1(0.9)$ & 4.3 & 0.229 & 0 & $1(2.1)$ & 0 & $1(0.9)$ & 5.1 & 0.527 & 0 & $1(2.1)$ & 0 & $1(1.0)$ & 6.10 .415 \\
\hline & Score 3+ & $6(8.6)$ & 0 & $6(5.5)$ & & & 1 (16.6) & $4(8.3)$ & $1(1.8)$ & $6(5.5)$ & & & 0 & $3(6.4)$ & $3(5.7)$ & $6(5.5)$ & \\
\hline & Total & 70 (64.2) & $39(35.8)$ & 109 (100) & & & $6(5.5)$ & $48(44)$ & $55(50.5)$ & $109(100)$ & & & $10(9.2)$ & $47(43.1)$ & $52(47.7)$ & $109(100)$ & \\
\hline \multirow[t]{3}{*}{ FISH } & Negative & $6(40.0)$ & $6(100)$ & $12(57.1)$ & & & 0 & $5(45.4)$ & $7(87.5)$ & $12(57.1)$ & & & 0 & $7(53.8)$ & $5(62.5)$ & $12(57.1)$ & \\
\hline & Positive & $9(60.0)$ & 0 & 9 (42.9) & - & 0.019 & $2(100)$ & $6(54.6)$ & $1(12.5)$ & 9 (42.9) & 6.3 & 0.043 & 0 & $6(46.2)$ & $3(37.5)$ & 9 (42.9) & - 0.999 \\
\hline & Total & $15(71.4)$ & $6(28.6)$ & $21(100)$ & & & $2(9.5)$ & $11(52.4)$ & $8(38.1)$ & $21(100)$ & & & 0 & $13(61.9)$ & $8(38.1)$ & $21(100)$ & \\
\hline
\end{tabular}

Data presented as number and percentage $-\mathrm{n}(\%)$. P...S, parameters; Bx-IHC, endoscopical mucosa biopsy samples immunohistochemistry score; R-IHC, tumor section of gastric resection immunohistochemistry score; FISH, fluorescence in situ hybridization.

Table 4. HER-2/neu status in primary and mucosal tumor tissues and HER-2/neu expression and amplification according to tumor location

\begin{tabular}{|c|c|c|c|c|c|c|c|c|c|c|c|c|c|}
\hline \multirow[b]{2}{*}{ Parameters } & \multirow[b]{2}{*}{ Category } & \multicolumn{5}{|c|}{$B x-I H C$} & \multirow[b]{2}{*}{$\chi^{2}$} & \multirow[b]{2}{*}{$p$} & \multicolumn{3}{|c|}{ Tumor location } & \multirow[b]{2}{*}{$\chi^{2}$} & \multirow[b]{2}{*}{$p$} \\
\hline & & 0 & 1 & 2 & 3 & Total & & & Cardia & Non-cardia & Total & & \\
\hline \multirow[t]{5}{*}{$\mathrm{R}-\mathrm{IHC}$} & Score 0 & $32(86.5)$ & $1(25)$ & 0 & 0 & $33(76.7)$ & \multirow{5}{*}{43.0} & \multirow{5}{*}{$<0.001$} & $27(79.4)$ & $61(81.3)$ & $88(80.7)$ & \multirow{5}{*}{2.3} & \multirow{5}{*}{0.517} \\
\hline & Score 1+ & $5(13.5)$ & $1(25)$ & 0 & 0 & $6(14.0)$ & & & $4(11.8)$ & $10(13.3)$ & $14(12.8)$ & & \\
\hline & Score 2+ & 0 & $1(25)$ & 0 & 0 & $1(2.3)$ & & & $1(2.9)$ & 0 & $1(1.0)$ & & \\
\hline & Score 3+ & 0 & $1(25)$ & 0 & $2(100)$ & $3(7.0)$ & & & $2(5.9)$ & $4(5.3)$ & $6(5.5)$ & & \\
\hline & Total & $37(86.1)$ & $4(9.3)$ & 0. & $2(4.6)$ & $43(100)$ & & & $34(31.2)$ & $75(68.8)$ & $109(100)$ & & \\
\hline \multirow[t]{3}{*}{ FISH } & Negative & $5(100)$ & $1(33.3)$ & 0 & 0 & $6(60.0)$ & \multirow{3}{*}{7.2} & \multirow{3}{*}{0.027} & $3(42.9)$ & $9(64.3)$ & $12(57.1)$ & & \multirow{3}{*}{0.397} \\
\hline & Positive & 0 & $2(66.7)$ & 0 & $2(100)$ & $4(40.0)$ & & & $4(57.1)$ & $5(35.7)$ & 9 (42.9) & - & \\
\hline & Total & $5(50.0)$ & $3(30.0)$ & 0 & $2(20.0)$ & $10(100)$ & & & 7 (33.3) & $14(66.7)$ & 21 (100) & & \\
\hline
\end{tabular}

Data presented as number and percentage $-\mathrm{n}(\%)$. Bx-IHC, endoscopical mucosa biopsy samples immunohistochemistry score; R-IHC, tumor section of gastric resection immunohistochemistry score; FISH, fluorescence in situ hybridization.

Table 5. Comparison of HER-2/neu gene expression and amplification in primary tumor foci

\begin{tabular}{lccccccc}
\hline R-IHC Scores & Score 0 & Score 1 & Score 2 & Score 3 & Total & $\chi^{2}$ & $p$ \\
\hline FISH(-) & 0 & $12(85.7)$ & 0 & 0 & $12(57.1)$ & & \\
FISH(+) & 0 & $2(14.3)$ & $1(100)$ & $6(100)$ & $9(42.9)$ & 14.0 & 0.001 \\
Total & 0 & $14(66.7)$ & $1(4.8)$ & $6(28.6)$ & $21(100)$ & & \\
\hline
\end{tabular}

Data presented as number and percentage $-\mathrm{n}(\%)$. R-IHC, tumor section of gastric resection immunohistochemistry score; FISH, fluorescence in situ hybridization.

In the ToGA study, chromosome 17 polysomy was found in only $4.1 \%$ of the entire population, including gene amplified cases [24]. In the present study, chromosome 17 polysomy was not detected.

As in breast cancers, it is stated that concordance rates between gene amplification and IHC scores outside of IHC2+ cases should be above $90 \%$ [31]. Cutsem et al reported that the concordance rate in $\mathrm{IHC} 3+$ cases was $94.9 \%$, while this rate in $\mathrm{IHC} 1+/ 0$ cases was $92.5 \%$ in the ToGA study [24]. Rüschoff et al reported a higher concordance rate (98\%) [30]. In another study [20], the concordance rate was reported as $94.5 \%$. Our overall concordance rate between IHC and FISH results in gastric resections was $90.5 \%$ and this was at the recommended threshold level (90\%). Our concordance rate was $100 \%$ in R-IHC3+ cases, while this rate only $85.7 \%$ in $\mathrm{R}-\mathrm{IHCO} / 1+$ cases. Our low compatibility rate in $\mathrm{R}-\mathrm{IHCO} / 1+$ cases might be due to tumor heterogeneity beside on preanalytical technical reasons in our procedure of IHC. The study material within the scope of tumor heterogeneity might be also responsible for the different rates observed in different studies. The materials used in the TOGA study were mucosa biopsies and resection materials [24]. The rates of gene overexpression and amplification detected on mucosa biopsies were higher than those of resections. Van Cutsem et al reported a higher overexpression rate in resection based analysis (23.2\% versus $19.7 \%$ ) [24]. One explanation for this difference might be different cut-off values on mucosa biopsies and resection materials. While the threshold value was accepted as $10 \%$ in resections, a cell cluster consisting of only 5 cohesive cells with complet/basolateral membranous immunostaining in mucosa biopsies was enough for the positivity [24].

HER-2/neu heterogeneity in GCa raises the question of how much mucosa biopsy samples are necessary for accurate HER$2 /$ neu analysis. Six to 8 biopsy samples representing tumors are suggested for IHC analysis [24]. IHC analysis on 1 or 2 mucosa samples will be far from accurate HER-2/neu analysis due to heterogeneity. In one study, it was suggested at least 8 mucosa samples for IHC analysis [32]. In our study, IHC analysis on mucosa biopsies was performed in 43 cases. The number of mucosa samples of 43 cases changed between 1 and 14 and the mean number of mucosa samples was 6 . This was consistent with the number recommended by the literature. The rate of $\mathrm{Bx}-\mathrm{IHC} 3+$ cases was $4.7 \%$. Our rate of $\mathrm{Bx}-\mathrm{IHC} 3+$ was lower than our rate of $\mathrm{R}$ $\mathrm{IHC} 3+$. Our compliance rate between $\mathrm{Bx}-\mathrm{IHC}$ and $\mathrm{R}-\mathrm{IHC}$ was $95.4 \%$ $(p<0.001)$. The rate of gene amplification corresponding to the 
cases with $\mathrm{Bx}-\mathrm{IHC} 1+$ was as high as $66.7 \%$. This result indicated that the cases with $\mathrm{Bx}-\mathrm{IHC1}+$ expression represented highly heterogeneous tumors and were not as balanced as the cases with $\mathrm{R}-\mathrm{IHC1+}$

Tumor heterogeneity appears to be a significant factor in evaluating HER-2/neu gene status. The frequency of heterogeneity in different studies ranged from $5 \%$ to $50 \%$ [2]. This high variability was likely due to differences in the definition of heterogeneity. The heterogeneity definitions by different authors were described as different threshold values (such as <10\%, 10\%-60\%, 5\%-50\% and $<66 \%$ of tumor cells) of strong HER2/neu expressions [2]. In the literature, it has been seen that there were many studies which had been performed on mucosa biopsies, whole sections (WS) and tissue microarrays (TMA) to better understand HER2/neu heterogeneity [14, 22, 33]. Different results were reported according to material analyzed in these studies. Tumor heterogeneity and sampling errors in TMA were suggested as the reason for this difference. Despite all this, Marx et al. reported that GCa were homogeneous for gene amplification in the TMAbased study [34]. In contrast, Hofmann and Lee were in an agreement on HER-2/neu heterogeneity of GCa [9, 35]. Fithy percent of the cases according to ToGA study were heterogeneous. $\mathrm{IHC} 1+/ 2+$ tumors were much more heterogeneous than $\mathrm{IHC} 3+$ tumors $(60 \%$ vs 30$)$ [24]. In a more comprehensive analysis of Warneke et al. [36], HER-2/neu positivity rates in WS and TMA were found as $8.1 \%$ and $6.3 \%$, respectively. In Warneke et al' study, the rates of FN and false positivity (FP) were $24 \%$ and $3 \%$, respectively [36]. The concordance rate between results of WS and TMA was $81.2 \%$ [36]. Lee et al. reported a concordance rate of 74.1\% between mucosa biopsy and WS [35]. Our FN rate in the mucosa biopsies was $4.65 \%$. Warneke et al [36] suggested that their high FN ratio was due to sampling error that was caused by HER-2/neu heterogeneity. Besides avoiding unnecessary Trastuzumab treatment, loss of treatment chance due to false negativity is also a very important question. Warneke et al indicated that IHC analysis should be performed in WS obtained from resections and that it would be useful to repeat the IHC analysis in metastatic foci, if primary tumor focus was negative for HER-2/neu [36].

\section{Conclusion}

Our HER-2/neu positivity rate was determined as $6.4 \%$ in our GCa cases by using IHC and FISH methods. Our compatibility rate between HER-2/neu overexpression and gene amplification in resection materials was $90.5 \%$. Our compatibility rate between Bx$\mathrm{IHC}$ and $\mathrm{R}-\mathrm{IHC}$ was $95,4 \%$. Our rates were consistent with the literature data. Our FN ratio in $\mathrm{Bx}-\mathrm{IHC}$ was $4.65 \%$ and it was low according to the literature. However, $\mathrm{Bx}-\mathrm{IHC1}+$ cases were evidently heterogenous for HER-2/neu expression. On the basis of our results, we suggest that HER-2/neu IHC should be performed on WS of resection materials and the assay should be repeated on different tumor areas of IHC negative cases. This strategy will greatly contribute to the detection of more patients who may benefit from trastuzumab treatment.

\section{Limitations}

Factors limiting our ability to comment on the results of the present study were as follows; although we performed HER-2/neu analysis on gastric resection material of 109 cases, HER-2/neu analysis could be carried out on endoscopic mucosa biopsies in only 43 cases. Other limiting factor was that FISH analysis could be performed in only 21 cases. Another important limiting factor was antibody clone we used.

\section{Conflict of interest}

The authors report no conflicts of interest.

\section{Funding}

This project was supported by Gaziosmanpaşa University Scientific Research Projects Committee (2013/73).

\section{Ethical approval}

All procedures performed in the present study were in accordance with the ethical standards of the institutional and/or national research committee and with the 1964 Helsinki declaration and its later amendments or comparable ethical standards. The present study is a retrospective study. For this type of study formal consent is not required.

\section{References}

1. Kamangar F, Dores GM, Anderson WF. Patterns of cancer incidence, mortality, and prevalence across five continents: defining priorities to reduce cancer disparities in differentgeographicregions of theworld. J Clin Oncol 2006; 24(14): 2137-2150. https://doi.org/10.1200/JCO.2005.05.2308.

2. Vakiani E. HER2 testing in gastric and gastroesophageal adenocarcinoma. Adv Anat Pathol 2015; 22(3): 194-201. https://doi.org/10.1097/PAP.0000000000000067.

3. TC Sağlık Bakanlığı. Türkiye Halk Sağığı Kurumu. Kanser Daire Başkanlığı [Health Ministry of Turkey. Public Health Agency of Turkey. Cancer Departments] https://hsgm.saglik.gov.tr/depo/birimler/kanserdb/istatistik/ANA rapor 2013v01 2.pdf

4. Harrison LE, Karpeh MS, Brennan MF. Extended lymphadenectomy is associated with a survival benefit for node-negative gastric cancer. $J$ Gastrointest Surg 1998; 2(2): 126-131. https://doi.org/10.1016/s1091255x(98)80002-4.

5. Mc Kenzie SJ, De Sombre KA, Bast BS, Hollis DR, Whitaker RS, Berchuck $A$, et al. Serum levels of HER-2 neu (C-erbB-2) correlate with overexpression of p185 neu in human ovarian cancer. Cancer 1993; 71(12): 3942-3946. https://doi.org/10.1002/10970142(19930615)71:12<3942::aid-cncr2820711224>3.0.co;2-3.

6. $\mathrm{Xu} \mathrm{YH,} \mathrm{Richert} \mathrm{N,} \mathrm{Ito} \mathrm{S,} \mathrm{Merlino} \mathrm{GT,} \mathrm{Pastan} \mathrm{I.} \mathrm{Characterization} \mathrm{of}$ epidermal growth factor receptor gene expression in malignant and normal human cell lines. Proc Natl Acad Sci U S A 1984; 81(23): 73087312. https://doi.org/10.1073/pnas.81.23.7308.

7. Gunturu KS, Woo Y, Beaubier N, Remotti HE, Saif MW. Gastric cancer and trastuzumab: first biologic therapy in gastric cancer. Ther Adv Med Oncol 2013; 5(2): 143-151. https://doi.org/10.1177/1758834012469429.

8. Slamon DJ, Leyland-Jones B, Shak S, Fuchs H, Paton V, Bajamonde A, et al. Use of chemotherapy plus a monoclonal antibody against HER2 for metastatic breast cancer that overexpresses HER2. N Engl J Med 2001; 344(11): 783-792. https://doi.org/10.1056/NEJM200103153441101.

9. Hofmann M, Stoss O, Shi D, Büttner R, van de Vijver M, Kim W, et al. Assessment of a HER2 scoring system for gastric cancer: results from a validation study. Histopathology 2008; 52(7): 797-805. https://doi.org/10.1111/i.1365-2559.2008.03028.x.

10. Pothos A, Plastira K, Plastiras A, Vlachodimitropoulos D, Goutas N, Angelopoulou R. Comparison of chromogenic in situ hybridisation with fluorescence in situ hybridisation and immunohistochemistry for the assessment of her- $2 /$ neu oncogene in archival material of breast carcinoma. Acta Histochem Cytochem 2008; 41(3): 59-64. https://doi.org/10.1267/ahc.07029. 
11. Jørgensen JT. Targeted HER2 treatment in advanced gastric cancer. Oncology 2010; 78(1): 26-33. https://doi.org/10.1159/000288295.

12. Park DI, Yun JW, Park JH, Oh SJ, Kim HJ, Cho YK, et al. HER-2/neu amplification is an independent prognostic factor in gastric cancer. Dig Dis Sci 2006; 51(8): 1371-1379. https://doi.org/10.1007/s10620-0059057-1.

13. Zhang $X L$, Yang YS, Xu DP, Qu JH, Guo MZ, Gong Y, et al. Comparative study on overexpression of her2/neu and her3 in gastric cancer. World J Surg 2009; 33(10): 2112-2118. https://doi.org/10.1007/s00268-0090142-z.

14. Takehana $T$, Kunitomo K, Kono K, Kitahara F, lizuka H, Matsumoto $Y$, et al. Status of c-erbB-2 in gastric adenocarcinoma: a comparative study of immunohistochemistry, fluorescence in situ hybridization and enzyme-linked immuno-sorbent assay. Int J Cancer 2002; 98(6): 833837. https://doi.org/10.1002/ijc.10257.

15. Aoyagi K, Kohfuji K, Yano S, Murakami N, Miyagi M, Takeda J, et al. Evaluation of the epidermal growth factor receptor (EGFR) and c-erbB2 in superspreading type and penetrating-type gastric carcinoma. Kurume Med J 2001; 48(3): 197-200. https://doi.org/10.2739/kurumemedj.48.197.

16. Brien TP, Depowski PL, Sheehan CE, Ross JS, McKenna BJ. Prognosticfactors in gastriccancer. Mod Pathol 1998; 11(9): 870-877. https://www.ncbi.nlm.nih.gov/pubmed/9758367.

17. Tanner $M$, Hollmen $M$, Junttila TT, Kapanen Al, Tommola S, Soini $Y$, et al. Amplification of HER-2 in gastric carcinoma: association with Topoisomerase Ilalpha gene amplification, intestinal type, poor prognosis and sensitivity to trastuzumab. Ann Oncol 2005; 16(2): 273278. https://doi.org/10.1093/annonc/mdi064.

18. Im SA, Kim JW, Kim JS, Kim MA, Jordan B, Pickl M, et al. Clinicopathologic characteristics of patients with stage III/IV $(M(0))$ advanced gastric cancer, according to HER2 status assessed by immunohistochemistry and fluorescence in situ hybridization. Diagn Mol Pathol 2011; 20(2): 94-100. https://doi.org/10.1097/PDM.0b013e3181fc02b7.

19. Kunz PL, Mojtahed A, Fisher GA, Ford JM, Chang DT, Balise RR, et al. HER2 expression in gastric and gastroesophageal junction adenocarcinoma in a US population: clinicopathologic analysis with proposed approach to HER2 assessment. Appl Immunohistochem Mol Morphol 2012; 20(1): 13-24. https://doi.org/10.1097/PAl.0b013e31821c821c.

20. Yan SY, Hu Y, Fan JG, Tao GQ, Lu YM, Cai X, et al. Clinicopathologic significance of HER-2/neu protein expression and gene amplification in gastric carcinoma. World J Gastroenterol 2011; 17(11): 1501-1506. https://doi.org/10.3748/wjg.v17.i11.1501.

21. Yan B, Yau EX, Bte Omar SS, Ong CW, Pang B, Yeoh KG, et al. A study of HER2 gene amplification and protein expression in gastric cancer. J Clin Pathol 2010; 63(9): 839-842. https://doi.org/10.1136/jcp.2010.076570.

22. Kim KC, Koh YW, Chang HM, Kim TH, Yook JH, Kim BS, et al. Evaluation of HER2 Protein Expression in Gastric Carcinomas: Comparative Analysis of 1414 Cases of Whole-Tissue Sections and 595 Cases of Tissue Microarrays. Ann Surg Oncol 2011; 18(10): 2833-2840. https://doi.org/10.1245/s10434-011-1695-2.

23. Jørgensen JT, Hersom M. HER2 as a Prognostic Marker in Gastric Cancer - A Systematic Analysis of Data from the Literature. J Cancer 2012; 3: 137-144. https://doi.org/10.7150/ica.4090.

24. Van Cutsem E, Bang YJ, Feng-Yi F, Xu JM, Lee KW, Jiao SC, et al. HER2 screening data from ToGA: targeting HER2 in gastric and gastroesophageal junction cancer. Gastric Cancer 2015; 18(3): 476484. https://doi.org/10.1007/s10120-014-0402-y.

25. Shah M, Khanin R, Tang L, Janjigian YY, Klimstra DS, Gerdes $H$, et al. Molecular classification of gastric cancer: a new paradigm. Clin Cancer Res 2011; 17(9): 2693-2701. https://doi.org/10.1158/1078-0432.CCR10-2203.

26. Rüschoff J. Adenocarcinoma of the GEJ: gastric or oesophageal cancer? Recent Results Cancer Res 2012; 196: 107-113. https://doi.org/10.1007/978-3-642-31629-6 7.
27. Van Cutsem E, Kang Y, Chung H, Shen L, Sawaki A, Hill FL, et al. Efficacy results from the ToGA trial: A phase III study of trastuzumab added to standard chemotherapy (CT) in first-line human epidermal growth factor receptor 2 (HER2)-positive advanced gastric cancer (GC). J Clin Oncol 2009; 27: 18_suppl. https://doi.org/10.1200/jco.2009.27.18 suppl.lba4509.

28. Bang YJ, Van Cutsem E, Feyereislova A, Chung HC, Shen L, Sawaki A, et al. Trastuzumab in combination with chemotherapy versus chemotherapy alone for treatment of HER2-positive advanced gastric or gastro-oesophageal junction cancer (ToGA): a phase 3, open-label, randomised controlled trial. Lancet 2010; 376(9742): 687-697. https://doi.org/10.1016/S0140-6736(10)61121-X.

29. EMEA, European Medicines Agency (2009): Opinion. https://www.ema.europa.eu/en/documents/smop/chmp-postauthorisation-summary-positive-opinion-herceptin en.pdf

30. Rüschoff J, Dietel M, Baretton G, Arbogast S, Walch A, Monges G, et al. HER2 diagnostics in gastric cancer-guideline validation and development of standardized immunohistochemical testing. Virchows Arch 2010; 457(3): 299-307. https://doi.org/10.1007/s00428-0100952-2.

31. Rüschoff J, Hanna W, Bilious M, Hofmann M, Osamura RY, Penault-Llorca F, et al. HER2 testing in gastric cancer: a practical approach. Mod Pathol 2012; 25(5): 637-650. https://doi.org/10.1038/modpathol.2011.198.

32. Möhler M, Al-Batran SE, Andus T, Anthuber M, Arends J, Arnold D, et al. S3-Leitlinie "Magenkarzinom” - Diagnostik und Therapie der Adenokarzinome des Magens und ösophagogastralen Übergangs (AWMF-Regist.-Nr. 032-009-OL) German S3-Guideline „Diagnosis and Treatment of Esophagogastric Cancer”. Z Gastroenterol 2011; 49(4): 461-531. German. https://doi.org/10.1055/s-0031-1273201.

33. Barros-Silva JD, Leitão $D$, Afonso L, Vieira J, Dinis-Ribeiro $M$, Fragoso $M$, et al. Association of ERBB2 gene status with histopathological parameters and disease-specific survival in gastric carcinoma patients. $\mathrm{Br}$ J Cancer 2009; 100(3): 487-493. https://doi.org/10.1038/sj.bjc.6604885.

34. Marx AH, Tharun L, Muth J, Dancau AM, Simon R, Yekebas E, et al. HER-2 amplification is highly homogenous in gastric cancer. Hum Pathol 2009; 40(6): 769-777. https://doi.org/10.1016/j.humpath.2008.11.014.

35. Lee $S$, de Boer WB, Fermoyle $S$, Platten M, Kumarasinghe MP. Human epidermal growth factor receptor 2 testing in gastric carcinoma: issues related to heterogeneity in biopsies and resections. Histopathology 2011; 59(5): 832-840. https://doi.org/10.1111/j.1365-2559.2011.04017.x.

36. Warneke VS, Behrens HM, Böger C, Becker T, Lordick F, Ebert MP, et al. Her2/neu testing in gastric cancer: evaluating the risk of sampling errors. Ann Oncol 2013; 24(3): 725-733. https://doi.org/10.1093/annonc/mds528.

\section{Authors:}

Ali Zisan Genc - MD, Research Assistant, Department of Pathology, Tokat Gaziosmanpasa University, School of Medicine, Tokat, Turkey. https://orcid.org/0000-0002-7084-1548.

Resit Dogan Koseoglu - Pathologist, Professor, Department of Pathology, Tokat Gaziosmanpasa University, School of Medicine, Tokat, Turkey. https://orcid.org/0000-0001-7389-6811.

Akgul Arici - Pathologist, Assistant Professor, Department of Pathology, Tokat Gaziosmanpasa University, School of Medicine, Tokat, Turkey. https://orcid.org/0000-0002-7347-9003.

Osman Demir - Biostatistician, Assistant Professor, Department of Biostatistics, Tokat Gaziosmanpasa University, School of Medicine, Tokat, Turkey. https://orcid.org/0000-0002-1322-2716. 